\title{
STATUS KARIES PADA GIGI BERJEJAL DI SD NEGERI 12 TUMINTING
}

\author{
${ }^{1}$ Dewi Malohing \\ ${ }^{2}$ P. S. Anindita \\ ${ }^{3}$ Paulina N. Gunawan
}

\author{
${ }^{1}$ Kandidat skripsi Program Studi Kedokteran Gigi Fakultas Kedokteran \\ Universitas Sam Ratulangi Manado \\ ${ }^{2}$ Bagian Ortodonsia Program Studi Kedokteran Gigi Fakultas Kedokteran \\ Universitas Sam Ratulangi Manado \\ ${ }^{3}$ Bagian Kedokteran Gigi Anak Program Studi Kedokteran Gigi Fakultas Kedokteran \\ Universitas Sam Ratulangi Manado \\ Email: dewi_270590@yahoo.com
}

\begin{abstract}
One of many dental problem has faced frequently by Indonesian people nowadays is dental caries, the other name for decay in teeth. The main factor leads into the caries is the setting of teeth (host) wich is out of the arch causing it hardly to be cleaned, tends to food and debris accumulated. These research aims to gain the image of the caries status for the crowding at tuminting $12^{\text {th }}$ elementary school public. DMF-T index is used for this caries examination. The research is presented into descriptions from, take student who have been fom ten to twelve years old with crowding conditions as population, then uses the total sampling method to determine sixty seven of them as sample. The result for crowding of the caries distribution shows that the range of DMF-T number is 0.7. it belongs to the low category, based on category of DMF-T index by WHO.
\end{abstract}

Keywords: caries, crowding.

\begin{abstract}
Abstrak: Salah satu masalah kesehatan gigi dan mulut yang dihadapi penduduk Indonesia adalah tingginya penyakit jaringan keras gigi atau karies. Karies gigi disebabkan oleh beberapa faktor. Salah satu faktor utama penyebab karies yaitu keadaan gigi (host), dimana posisi gigi dengan posisi keluar dari lengkung rahang, menyebabkan kesulitan pembersihan. Kondisi ini cenderung membuat makanan dan debris terakumulasi. Tujuan dari penelitian ini yaitu untuk memperoleh gambaran status karies pada gigi berjejal di SD Negeri 12 Tuminting. Pemeriksaan karies menggunakan indeks DMF-T.

Penelitian ini merupakan penelitian deksriptif. Populasi dari penelitian ini yaitu siswa usia 1012 tahun dengan kondisi gigi berjejal. Sampel berjumlah 67 orang dan pengambilan sampel dilakukan dengan metode total sampling.

Hasil penelitian tentang distribusi karies pada gigi berjejal menunjukkan rata-rata jumlah DMF$\mathrm{T}$ ialah 0,7 dan menurut kategori indeks DMF-T dari WHO termasuk pada kategori sangat rendah.
\end{abstract}

Keyword: karies, gigi berjejal.

Salah satu masalah kesehatan gigi dan mulut yang dihadapi penduduk Indonesia adalah tingginya penyakit jaringan keras gigi atau karies. Survei Riset Kesehatan Dasar (Riskesdas) nasional tahun 2007 menunjuk- kan prevalensi karies di Indonesia mencapai 72,1\%. Riskesdas nasional 2007 juga melaporkan bahwa skor DMF-T (D: decayed: gigi yang karies, $\mathrm{M}$ : missed: gigi yang hilang, F: filled: gigi yang ditumpat) di 
Indonesia mencapai 4,85 . $^{1}$

Karies gigi merupakan suatu proses kerusakan yang dimulai dari email berlanjut ke dentin yang disebabkan oleh beberapa faktor. Salah satu faktor utama penyebab karies yaitu keadaan gigi (host), dimana posisi gigi dengan posisi keluar dari lengkung rahang, menyebabkan kesulitan pembersihan. Kondisi ini cenderung membuat makanan dan debris terakumulasi. $^{2}$ Kecenderungan terjadinya karies meningkat pada keadaan gigi yang berjejal. Proses bakterial pada karies secara progresif dapat menyebabkan kerusakan pada struktur jaringan keras gigi. ${ }^{4}$

Penelitian di Poland pada tahun 2010 menunjukan bahwa prevalensi karies dan DMF-T pada gigi anterior dengan gigi berjejal lebih tinggi dari pada gigi yang tidak berjejal. ${ }^{3}$ Penelitian di Hungria pada tahun 2012 juga menunjukan hubungan antara maloklusi dengan skor DMF-T secara statistik lebih tinggi dibanding pada remaja yang tidak mengalami kelainan susunan gigi. $^{4}$

Penelitian dilaksanakan di Sekolah Dasar (SD) Negeri 12 Tuminting karena di SD tersebut belum pernah dilakukan penelitian. Selain itu sekolah ini juga belum memiliki program Usaha Kesehatan Gigi Sekolah (UKGS). Penelitian tentang status karies pada gigi berjejal ini akan dilakukan pada murid yang berusia 10-12 tahun, karena sebagian besar anak pada usia tersebut gigi permanen sudah erupsi.

Berdasarkan latar belakang tersebut, maka peneliti tertarik melakukan penelitian mengenai Status Karies Pada Gigi Berjejal di SD Negeri 12 Tuminting.

\section{METODE PENELITIAN}

Jenis penelitian ini merupakan penelitian deskriptif. Penelitian dilakukan di SD Negeri 12 di kecamatan Tuminting Manado Sulawesi Utara. Waktu penelitian dilaksanakan pada bulan Maret 2013. Populasi dalam penelitian ini adalah anak usia 10-12 tahun dengan kondisi gigi berjejal berjumlah 67 orang. Kriteria inklusi dalam penelitian ini yaitu anak dengan gigi permanen saja, bersedia dan dijinkan oleh orang tua untuk dijadikan subjek penelitian dan bersifat kooperatif selama pengambilan data. Subjek penelitan yang tidak berada di tempat saat penelitian dilakukan dimasukkan dalam kriteria eksklusi. Metode pengambilan sampel yaitu Total Sampling.

Pengambilan data karies gigi pada siswa dilakukan dengan cara mengumpulkan subjek penelitian di salah satu ruang kelas untuk melakukan pemeriksaan. Pemeriksaan dilakukan selama satu hari.

Subjek penelitian dipanggil satu persatu dan diinstruksikan untuk duduk tenang, kemudian diinstruksikan membuka mulut. Karies gigi diperiksa menggunakan kaca mulut dan sonde, kemudian diperiksa menggunakan indeks DMF-T dengan melihat jumlah gigi karies (Decay), gigi yang hilang karena karies (Missing) dan gigi yang ditumpat akibat karies (Filling).

Pemeriksaan DMF-T dilakukan dengan memeriksa 28 gigi yang ada. Jumlah DMF$\mathrm{T}$ rata-rata dihitung dengan cara menjumlahkan jumlah gigi yang karies, hilang dan ditambal lalu dibagi dengan jumlah populasi. $^{7}$

$$
\text { Indeks DMF-T }=\frac{\mathrm{D}+\mathrm{M}+\mathrm{F}}{\text { Jumla } h \text { Populasi }}
$$

Kategori status karies berdasarkan jumlah DMF-T rata-rata menurut WHO mulai dari tingkat sangat rendah sampai sangat tinggi, dapat dilihat pada Tabel 1.

Tabel 1. Kategori DMF-T. ${ }^{8}$

\begin{tabular}{cc}
\hline Skor & Kategori \\
\hline $0,0-1,1$ & Sangat rendah \\
$1,2-2,6$ & Rendah \\
$c, 7-4,4$ & Sedang \\
$4,5-6,5$ & Tinggi \\
$>6,6$ & Sangat Tinggi \\
\hline
\end{tabular}

Data yang didapat kemudian dicatat dan dimasukkan dalam tabel kerja, diolah berdasarkan distribusi frekuensi kemudian disajikan dalam bentuk diagram. 
96 Jurnal e-GiGi (eG), Volume 1, Nomor 2, September 2013, hlm. 94-98

\section{HASIL PENELITIAN}

Penelitian dilaksanakan di SD Negeri 1 Tuminting. Subjek penelitian yang didapatkan berdasarkan kriteria inklusi berjumlah 67 orang dan distribusi berdasarkan jenis kelamin dapat dilihat pada Gambar 1.

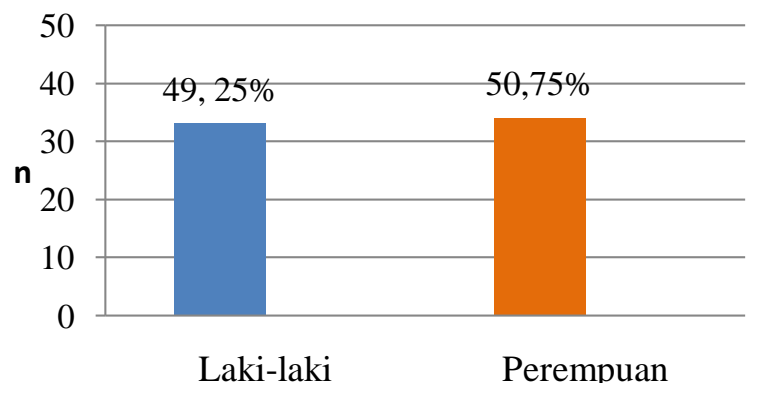

Gambar 1. Diagram distribusi subjek penelitian berdasarkan jenis kelamin.

Gambar di atas menunjukkan bahwa berdasarkan jenis kelamin didapati jumlah siswa laki-laki dan perempuan hanya selisih satu orang. Siswa laki-laki sebanyak 33 orang $(49,25 \%)$ dan siswa perempuan sebanyak 34 orang $(50,75 \%)$.

Hasil pemeriksaan karies berdasarkan jumlah mahasiswa yang terpapar karies dan bebas karies dapat dilihat pada Gambar 2.

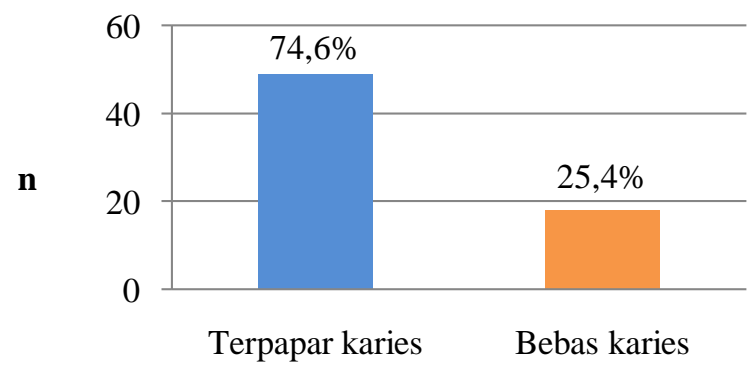

Gambar 2. Distribusi jumlah subjek penelitian yang terpapar karies dan bebas karies.

Gambar di atas menunjukkan bahwa sebagian besar siswa dengan kondisi gigi berjejal 49 orang $(74,6 \%)$ terpapar karies sedangkan sisanya 18 orang $(25,4 \%)$ bebas karies.

Hasil pemeriksaan karies berdasarkan distribusi komponen DMF-T dapat dilihat pada diagram (Gambar 3).

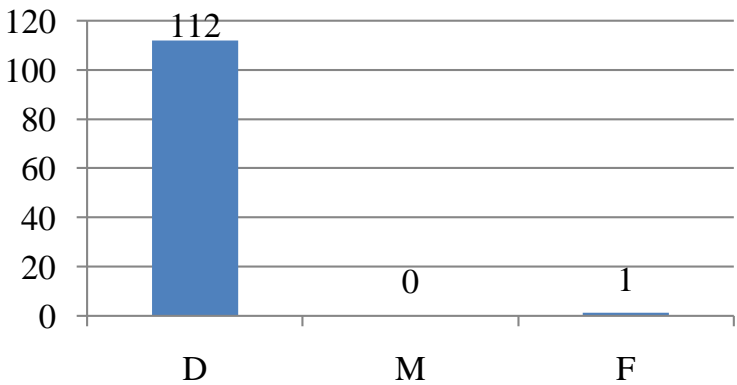

Gambar 3. Diagram distribusi komponen DMF-T.

Gambar di atas menunjukkan bahwa hanya komponen $\mathrm{D}$ dan $\mathrm{F}$ yang ditemukan pada subjek penelitian yang diperiksa, dan tidak terdapat komponen $\mathrm{M}$.

Keadaan karies pada mahasiswa pengguna alat ortodontik cekat dapat ditentukan dari jumlah DMF-T rata-rata yang diperoleh melalui hasil pembagian dari jumlah ketiga komponen DMF-T di atas dan jumlah subjek penelitian. Hasil pemeriksaan status karies berdasarkan jumlah DMF-T dapat dilihat pada gambar 4 .

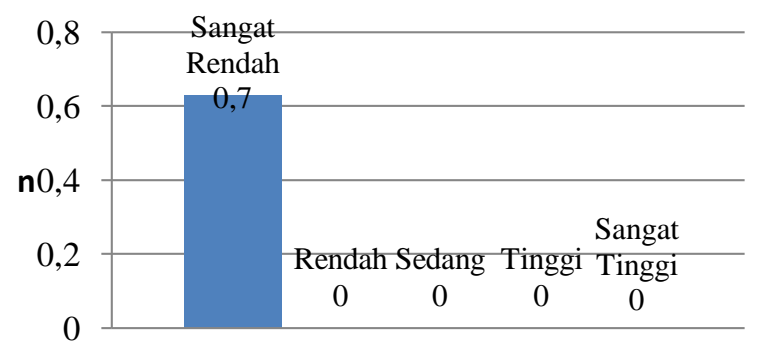

Gambar 4. Kategori status karies gigi berdasarkan indeks DMF-T.

Jumlah DMF-T rata-rata ialah 1,7 dan menurut kategori indeks DMF-T termasuk pada kategori rendah.

\section{BAHASAN}

Hasil pemeriksaan karies pada 67 murid yang menjadi subjek penelitian didapatkan lebih banyak siswa yang terpapar karies yaitu sebanyak 49 orang $(74,6 \%)$ dan sebanyak 18 orang siswa (25,4\%) bebas karies (Gambar 6). Penyebab munculnya karies tersebut dipengaruhi oleh 
perilaku menjaga kebersihan gigi dan mulut siswa. Permukaan gigi yang tidak disikat dengan benar dapat menyebabkan sisa makanan menumpuk di sekitar gigi sehingga memicu terjadinya pembentukan plak. Apabila perilaku kebersihan mulut tersebut tidak diubah, maka lama-kelamaan proses pembentukan karies bisa terjadi dan semakin parah. Menurut Notoatmojo, kebiasaan menjaga kebersihan gigi dan mulut sebagai bentuk perilaku yang didasari oleh pengetahuan akan mempengaruhi baik atau buruknya kesehatan gigi dan mulut.

Hasil pemeriksaan dengan menggunakan indeks DMF-T (Gambar 7) menunjukan jumlah komponen yang paling banyak yaitu komponen D sebanyak 112 gigi yang karies, sedangkan untuk komponen $\mathrm{M}$ tidak ada gigi yang hilang akibat karies dan komponen $\mathrm{F}$ yaitu gigi yang di tumpat hanya 1 gigi. Banyaknya jumlah gigi yang karies mengindikasikan bahwa siswa belum menerapkan kebiasaan menyikat gigi setelah sarapan dan sebelum tidur. Hal ini bisa dikaitkan dengan tidak adanya program UKGS di sekolah ini, sehingga mengakibatkan siswa belum memahami betapa pentingnya menjaga kesehatan gigi dan mulut. Karies yang muncul juga sebagian besar merupakan karies email tidak terdapat gigi yang hilang karena karies maupun gigi yang diindikasikan untuk dicabut. Sebagian besar gigi yang terkena karies yaitu gigi geraham.

Hanya terdapat satu gigi dari satu satu murid yang ditumpat giginya. Hal ini mengindikasikan bahwa siswa kurang menyadari untuk menjaga kesehatan mulutnya sendiri, karena pengetahuan tentang memelihara kesehatan gigi dan mulut masih tergolong rendah. Anak seusia ini masih sangat bergantung pada orang tua. Orang tua siswa hanya lebih memilih untuk membiarkan gigi anaknya berlubang daripada ditumpat karena ekonomi yang lemah. Hal ini didukung oleh penelitian yang dilakukan Sogi dan Basgar pada siswa sekolah di India menunjukan status karies lebih baik pada anak dengan status pekerjaan orang tua menengah ke atas dibandingkan dengan pekerjaan orang tua menengah ke bawah.

Jumlah DMF-T rata-rata pada subjek penelitian yang diperiksa yaitu 1,7 (Gambar 4). Berdasarkan kategori karies menurut WHO termasuk dalam kategori status karies rendah. Hasil penelitian ini tidak sejalan dengan penelitian yang dilakukan Buczkowska yang menunjukan prevalensi karies pada anak dengan kondisi gigi berjejal tergolong tinggi. ${ }^{4}$ Rendahnya status karies pada penelitian ini dapat disebabkan karena subjek pada penelitian ini ialah siswa SD yang berusia 10-12 tahun sedangkan subjek penelitian dari Buczkowska ialah anak yang berusia 15-19 tahun, dimana anak dengan usia 15-19 tahun giginya sudah terpapar lebih lama di dalam mulut sehingga semakin berpotensi mengalami karies. Karies berkembang membutuhkan waktu yang cukup lama, tidak dalam hitungan hari atau minggu melainkan bulan atau tahun. Hal ini didukung oleh penelitian yang dilakukan oleh Hafez dkk yang menyatakan bahwa prevalensi karies pada anak dengan kondisi gigi berjejal lebih rendah dibandingkan pada usia dewasa. ${ }^{7}$

\section{SIMPULAN}

Penelitian ini menunjukan bahwa status karies siswa dengan kondisi gigi berjejal di SD negeri 1 Tuminting termasuk pada kategori rendah. Diperlukan peran orang tua dalam memperhatikan kesehatan gigi dan mulut anak.

\section{UCAPAN TERIMA KASIH}

Penulis mengucapkan terima kasih kepada drg. Ni Wayan Mariati, Mkes (Dosen penguji I) dan drg. Dinar Wicaksono, Sp.KG (Dosen penguji II) atas masukan yang telah diberikan kepada penulis. Penulis juga mengucapkan terima kasih kepada semua pihak yang telah membantu penulis dalam menemukan ide dalam penulisan karya tulis ini.

\section{DAFTAR PUSTAKA}

1. Badan Peneliti dan Pengembangan Kesehatan RI. Laporan hasil riset kesehatan 
98 Jurnal e-GiGi (eG), Volume 1, Nomor 2, September 2013, hlm. 94-98

dasar nasional tahun 2007. Jakarta: Departemen Kesehatan RI, 2008; p.129-46.

2. Mansjoer A, Triyanati K, Savitri R, Wardhani,WI, Setiowulan W. Kapita Selekta kedokteran Jilid 1 (Edisi Ketiga). Jakarta: Media Aesculapius FKUI, 1999; p.151-57.

3. Buczkowska J, Szyszka L, Wozniak K. Anterior tooth crowding and prevalence of dental caries in children in Szczecin, Poland. Dental Health. 2012:29(2):1.

4. Masidin. Prevalensi pada remaja-remaja di hungria. [homepage on the Internet]. Nodate [cited 2012 Des 03]. Available from: http://www.prevalensi-maloklusipada-remaja\%20crowding-karies

5. Hafez HS, Shaarawy SM, Al-Sakiti AA, Mostafa YA. Dental crowding as a caries risk factor. USA: EBD, 2013; p.443-5. 